\title{
Exploring the Undergraduate Students Perception on Translation - A Preliminary Step to Teach Translation in EFL Classes
}

\author{
Roswani Siregar ${ }^{1}$ \\ ${ }^{1}$ Department of Economics, Universitas Al-Azhar, Medan, Indonesia \\ Correspondence: Roswani Siregar, Department of Economics, Universitas Al-Azhar, Medan, Indonesia. E-mail: \\ roses_air@yahoo.com
}

Received: July 3, 2018 Accepted: August 12, 2018 Online Published: August 14, 2018

doi: 10.5539/elt.v11n9p90 URL: http://doi.org/10.5539/elt.v11n9p90

\begin{abstract}
As we live in a world where English is a dominant language and the use of communication technology become part of our daily lives, we encounter many opportunities that deals with it. The studies on integration of translation-based learning activities in English as Foreign Language (EFL) classrooms is growing in recent years. But little known in Indonesia. The aim of this study is to explore the students perception on the current EFL learning in classroom, and their perception on translation as useful tools in language learning. The students perception is collected by online-questionnaire via Google Forms. The questionnaire comprises of ten questions that covers the students experiences in translation, learning methods, translation aid tools, preferred text materials, course length expection and willingness to attend the course. Based on data analysis result, the student perception and willingness to learn translation is determined. Student perception is crucial factor for teacher in helping the student to develop an effective learning and develop translation course design in university setting.
\end{abstract}

Keywords: teaching, translation, learning, student, perception

\section{Introduction}

Many EFL teachers in Indonesia will hesitate to teach translation course in non-translation class. Generally translation teaching conducts in English Department (Ardi, 2012; Sunardi, 2017). Although most of them believe that translation as an aspect of language acquisition that useful and benefit for students, they are not sure whether students will be motivated to attend the course. The main reason is, students rely on translation automation technologies or machine translation such as google translate rather than attend the conventional course that time-consuming. Another reason is, teaching translation involves much theoretical matters, manual words checking and pairing activity - things that bored for techy-students.

In our globalised world with multilingual societies translation is obvious act of communication. Thus, translation is a useful skill, not just for professional translators and interpreters, but also for academic community.

The integration of translation-based learning activities in EFL classrooms has been controversy since two last decades. In 1990-s few studies considered translation is worthed to be integrated and practiced in EFL classroom, despite no one well-established methodology to consider it as didactic tools (Atkinson, 1993, Conacher, 1996; Eadie, 1999; Ellis, 1992; Harmer, 1991; Ur, 1996;). However the attention to translation as pedagogical tool in EFL classroom is still growing. Other studies perceive translation extremely important for foreign language teaching for it allows conscious learning, where process of mental translation going on throughout the process of language learning (Shiyab \& Abdul, 2001). It also regarded as motivating activity because of translation in classroom involving the exercises (Lavault in Mogahed 2011, Carreres, 2006). Herman in Hung (2002: 14) argues that translating is not an innate skill, it has to be learned and negotiated, both cognitively and normatively.

Although there is skeptism about translation in EFL classroom, Calis and Dikilitas (2012: 5083) report the benefit of translation practice in EFL clasroom. They emphasis that translation was not designed to prepare the learners to be translators as a profession, but to create better foreign language learning by translation.

By taking into account the findings of the aforementioned studies and the relevant study is rarely found in Indonesia, this study is aimed to explore the students perception on the current EFL learning in classroom, and their perception on translation as useful tools in language learning. Thus, these two specific questions will be addressed: is translation favorably in non-translation class? Do the students motivated to learn translation and 
aware the benefit of it? The identification of students perception can be a basis in designing translation course and as part of further attempt to develop an effective translation teaching model that hopefully lead to raise the student awareness on importance of EFL acquisition in university setting.

\section{Literature Review}

\subsection{Students Perception on Translation}

Studies shows that student perceptions are an important factors of student behaviour and it can be a basis for designing the teaching model that optimizing the learning outcomes. Students' perceptions reflects how, why, and what students learn. As previously stated, the purpose of this study is to investigate the students perception on translation. The studies shows that investigation on student perception is crucial in EFL teaching. As depicted by Flórez, et al. (2012: 113) student has different opinions about the course, its content and objectives, its level of difficulty, the time students invested in the course, adults' learning, and the role of the teacher. Wang (2009: 149) found the similarities and differences between teacher and student perceptions regarding the role of fluency and accuracy in language teaching and learning. Wang also suggest that translation is an useful tool in learning and there should be more translation exercises.

\subsection{Problems in Incorporating Translation into Non-Translation Class}

The investigation on the students perception also addressed another question, wheter translation is favorable in non-translation class, and do the students motivated to learn it by aware the benefit of it.

Studies have shown that teaching translation to students in non-translation class may be overwhelming activities. Larson (1986: 67) depicted those who are learning the target language at the same time encounter two major issues: first of all, the fact that learning how to cope with translation-related problems is not exactly the same as learning the language itself, although they go hand-in-hand. Second, it is vital to decide which teaching translation method is better to be used along with the method adopted for translation. In line with the teaching, Vermes (2010: 83-85), argued that an essential requirement to consider translation a valid didactic tool is to distinguish pedagogical from real translation in terms of their function, the object being dealt with and the addressee. As for the function, pedagogical translation is basically instrumental insofar as the translated text is a mere tool to improve students' second language (L2) proficiency.

\subsection{Emphasizing the Benefit of Translation}

When asked about the importance of language skill, no one academic community doubt about. Translation may perceived as the fifth language skill beside the other four basic skills such as listening, speaking, reading, writing. Translation posited in a special stage of language teaching. As Rose (2000: 61) argued, translation is the most important social skill since it promotes communication and understanding between strangers.

However, there are people assume that skill in translation cannot be learned and, especially cannot be taught. They believe that some people are born with talent of being in languages and become good translators or interpreters. Tisgam (2009: 456) concluded that translation is teachable because it is a craft and consequently teachable as are other crafts. Believing that translation is a teachable craft, teachers should help their students get an insight into the nature of translation and recognize that it is vital for them to pay attention to translation theories while sharpening their translation skills. They should also be aware that ignoring the above-mentioned points leads to students' confusion, lack of motivation, and loss of interest in the curriculum.

The main purpose of translation teaching should be that of training and preparing good professionals who will in turn successfully make a living out of their studies making thus the students responsible for the act of translating and its importance. As Popovic (2001: 2) stated, the purpose of translation teaching in the classroom is not to train professionals, but to help learners develop their knowledge of English. In other words, it is a means to an end, not an end to be achieved. However, some learners may become translators one day, and the basic knowledge of translation that they have gained in the classroom can serve as a solid ground for building up translation skills.

In designing a translation course, the teachers should assure that students who take the course will practice translating as much as possible. It must aim, at least, at developing the student's insight into the nature and significance of translation as such, as a result of the confrontation between the mother tongue and the foreign language while searching for equivalence in meaning and broadening the student's competence in the mother tongue and the foreign language.

Calis and Dikilitas (2012: 5083) emphasis on the benefits of translation for L2 learning. Their study evidenced that these activities were not designed with the aim of preparing best translators as a profession, but to create better foreign language learning via translation. Kelly and Bruen (2015: 13) mentioned translation and its role in 
vocabulary building. Ivone (2005) shows that English learners experience translation as default method of vocabulary learning. It is useful teaching and learning tool which can complement existing pedagogical approaches as one component of an eclectic approach to language teaching and learning. However, scholars have pointed out that by using translation students may enhance their knowledge of the L2, mainly through contrastive analysis. The interference between the L1 and the FL can be used to promote language learning (Cuéllar in Aquado \& Becerra, 2013: 42).

\subsection{Student Motivation}

As motivation is considered one of the factors leading to success, the researchers also studied the activities students considered necessary for a researcher to determined the students willingness and as basis for teacher to develop an effective course design. As Littlewood (1987: 53) observes that in EFL learning as in every other field of human learning, motivation is the critical force which determines whether a learner embarks on a task at all, how much energy he devotes to it, and how long he perseveres. It is a complex phenomenon and includes many components: the individual's drive, need for achievement and success, curiosity, desire for stimulation and new experience, and so on. These factors play a role in every kind of learning situation.

Reeve (2009: 169) argued the nurturing inner motivational resources is important when teachers transition to or introduce a new learning activity and seek student initiative. student motivation is influenced by both internal and external factors that can start, sustain, intensify, or discourage behaviour.

\section{Methods}

\subsection{Place and Participants}

The study was conducted in the Department of Economics and Engineering, Universitas Sumatera Utara in Medan - Indonesia. A survey was conducted to explore the students' perceptions on current English subject learning, motivation and interest in translation learning. The participants in this study were 59 undergraduate students (32 were Economic Faculty Students and 27 were Engineering) who attend the English subject in first and third semester. By the year of formal education, they have an average English learning experience at least of 14 years in formal education. Thus their English proficiency levels are considered suitable for this study. All of participating students agreed to fill out the questionnaire and attend the preliminary translation test that took two sessions with total time 4 hours. This study was conducted in November 2017.

\subsection{Instruments and Data Collection}

The survey of student perception was administered by online-questionnaire (Google form). The questionnaire consisted of 20 semi-structured questions with a mixture of closed-ended and open-ended questionnaires that allow for in-depth information from the students.

The data collection can be devided into six sections that draws the student perception on importance of english subject matters in translation; students' experience on translation assignment, the usefulness of translation skill; preferred translation methods and material; translation learning methods; students willingness and course length expectation. With extensive literature review, a table of specification with the initial items was created to guide item construction for developing the scale, we were able to identify students' perception and expectation on translation in classroom.

\subsection{Administration to Students}

The online-questionnaire of student perception (OSP) using Google Form was distributed by email to undergraduate students who agree and voluntary listed their email on the population list $(n=59)$. Fifty-six students (56/59 or 94.91\%) returned the completed OSP. Students were asked to rate on a 3-point Likert-type scale (from A $=$ Preferred/Agree; $\mathrm{B}=$ Less preferred/Less agree, and $\mathrm{C}=$ Unpreferred/Disagree) their perceptions on current EFL learning. The space was provided to facilitate their feedback on open-ended question. All students were also asked to rate their expectation on translation course. Completed responses and consent on OSP were returned via e-mail to the investigator and recorded with the students registration. The voluntary students provided their consent to participate in this study.

\section{Results and Discussion}

Throughout the students feedback on online-questionnaire, the researchers gathered important data as regards the quantity and quality of students' perception and motivation on current English learning and translation. 
Table 1. Students perception measured items

\begin{tabular}{|c|c|c|c|}
\hline \multicolumn{2}{|c|}{ Questionnaire Items } & \multicolumn{2}{|l|}{ Options } \\
\hline \multicolumn{4}{|c|}{ A. Student perception on importance of english subject matters in translation } \\
\hline \multirow[t]{2}{*}{1} & \multirow{2}{*}{$\begin{array}{l}\text { Importance of English subject to } \\
\text { translation }\end{array}$} & 1) Listening & 2) Speaking \\
\hline & & 3) Reading & 4) Writing \\
\hline \multicolumn{4}{|c|}{ B. Students experience on translation assignment } \\
\hline & \multirow{3}{*}{$\begin{array}{l}\text { Translation assignment students had } \\
\text { before }\end{array}$} & \multicolumn{2}{|c|}{ 1) no assignment } \\
\hline & & \multicolumn{2}{|c|}{ 2) 1 to 3 assignment(s) } \\
\hline & & \multicolumn{2}{|c|}{ 3) more than 3 assignments } \\
\hline & Translation aids/tools & \multicolumn{2}{|c|}{ 1) Manual translation by using dictionary/online dictionary } \\
\hline & & \multicolumn{2}{|c|}{ 2) Using machine translation/software } \\
\hline & & \multicolumn{2}{|c|}{ 3) Using translation service } \\
\hline
\end{tabular}

C. Students perception on usefulness of translation skill

4 Usability of translation

1) Help students for further information resources in English

2) Finding better job or career

3) A skill students need for higher education

D. Preferred translation methods and material

5 Translation methods

1) Grammar based Translation

2) Grammar rules

4) Meaningful texts and vocabulary

6 Written material in translation:

1) General text (newspaper and magazine articles)

2) Literary text (novels, drama, poetry)

3) Specific text (contracts, legal and scientific texts)

E. Preferred learning methods

7 Learning methods

1) Cooperative Learning

2) Task-based learning

$8 \quad$ Clasroom interaction

1) Student - teacher interaction

2) Individual learning

3) Workgroup / discussion

F. Student willingness and course length expectation

9 Willingness to attend the translation course

10 Expectation to time invested

$\leq 3$ month $=3$ sessions per week

3-4 months $=2$ sessions per week

5-6 months $=1$ session per week

\subsection{Student Perception on Importance of English Subject Matters in Translation}

The students who perceive the English subject matters are important in translation is ranked as follows: listening 35 (35.7\%), speaking $41(80.4 \%)$, reading $20(73.2 \%)$, and writing $45(73.2 \%)$.

The table below show the students different perception on importance of English subject to translation. Writing skill is placed in the first rank. Students opinion depict that they are aware about the English written is important in written communication. Some students includes it practical benefit in professional fields such as business, education, information technology, medicine, science, etc. Having a good writing English skills also important in academic achievement. 


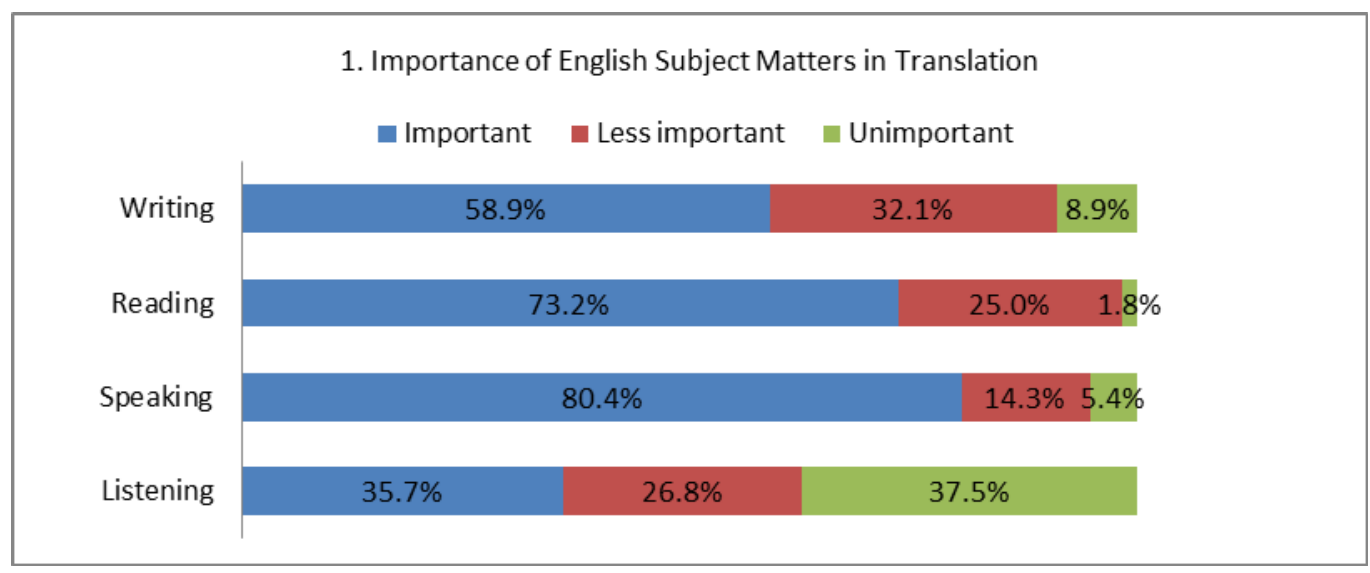

Figure 1. Importance of English subject matters in translation

Listening plays an important role in communication as it is said that, of the total time spent on communicating. Listening is the primary means by which incoming ideas and information are taken in (Devine: 1982). In this study speaking and listening skill is posited in the second and third place. Based on questionnaire result, 33 (58.9\%) students perceive that listening skills were important. The students commentaries suggest that having good English command means having great opportunities for a well paid and interesting career. Some students apparently perceive translation is interpreting. They say, both speaking and listening is a must in translation.

According to students response, reading is the less important language skill in translation. But their open responses to it apparently reverse. Some students say they enjoy reading the news, but it doesn't much contribute to translation skill. Another one student wrote that they did not like reading long passages. Those who enjoy the reading in class says that they most enjoy the reading related the topic of study.

\subsection{Students Experience on Translation Assignment}

Students responds to experiences on translation assignments is ranked as follows: most of students (31) has had 1 to 3 assignment(s) and 25 students has had more than 3 assignments. The subject of translation text assignment is part of other subject materials such as economic and engineering text books.

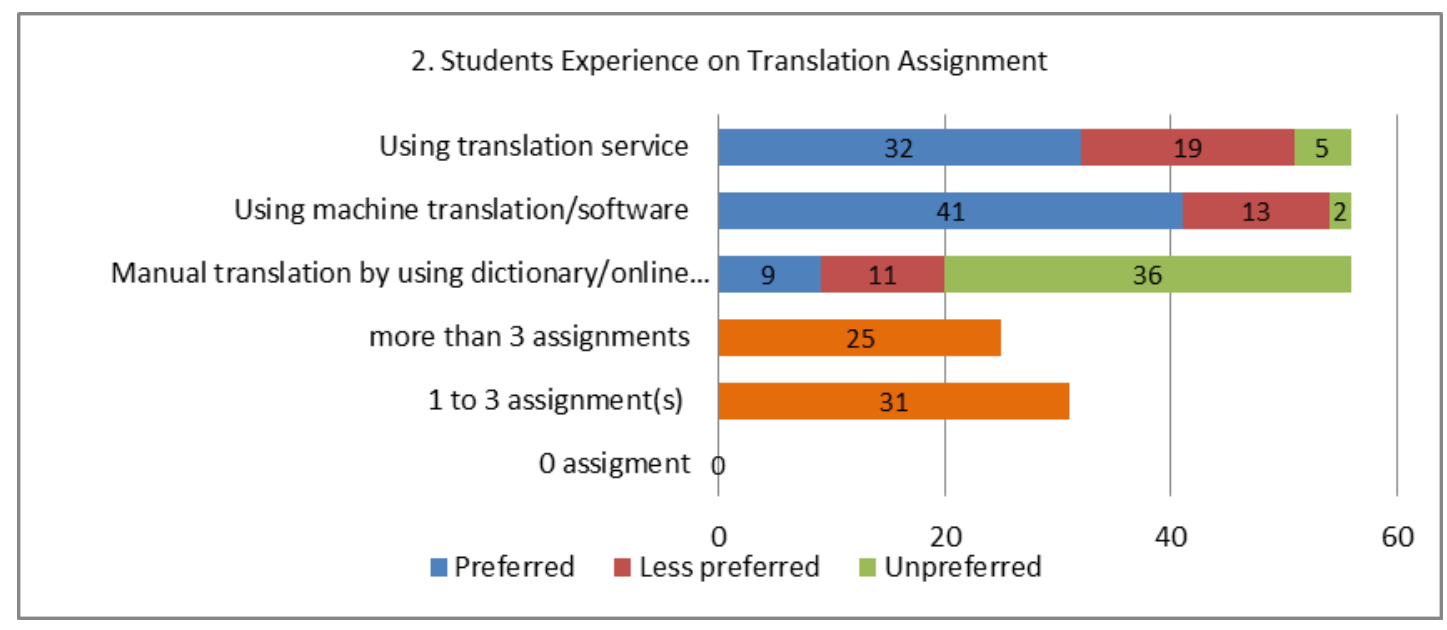

Figure 2. Students experience on translation assignment

Machine translations/software were used in assisting students in translation assignment. 41 students reported use Google Translator to translat source texts to target texts both for English into Indonesian and vice versa. Open responded questionnaire shows the students also used Google Translator to translate foreign words such as popular 
quotes, short phrases, read webpage, email, and article.

\subsection{Students Perception on Usefullness of Translation Skill}

There are 3 choices offered for the students concerning the usefulness of translation in learning. The sequences of most responses show us the students perception on translation. In the first place, 40 students (71.4\%) responded that translation help them to find better job or career. In the second place, 36 students perceive the translation skill help them in finding more information in English language resources. While 27 students (64.1) believe that translation skill is needed in higher education.

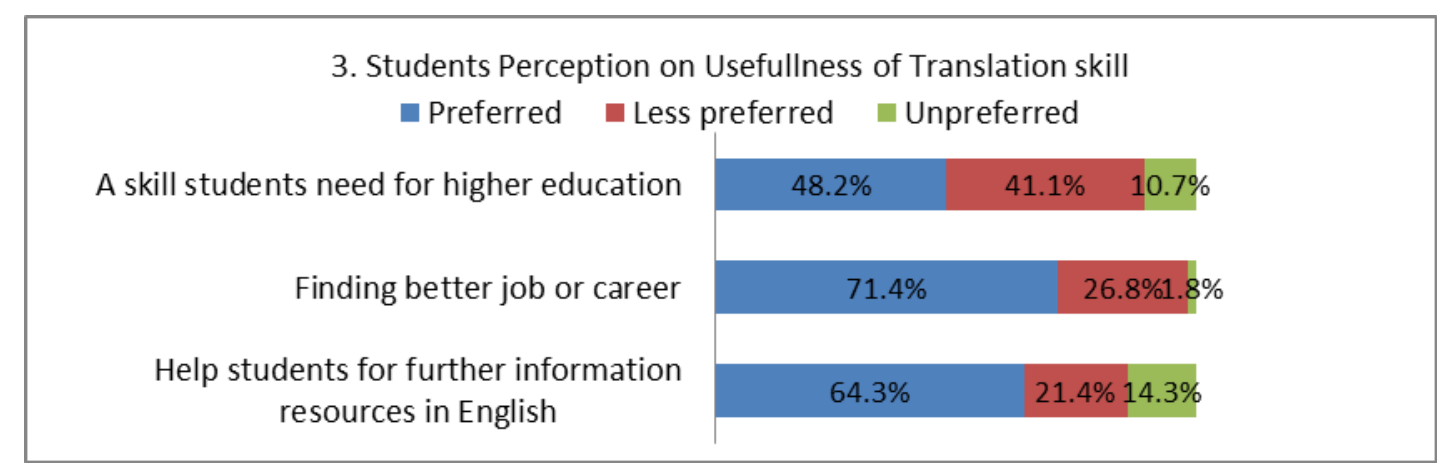

Figure 3. Students perception on usefullness of translation skill

\subsection{Preferred Translation Methods and Materials}

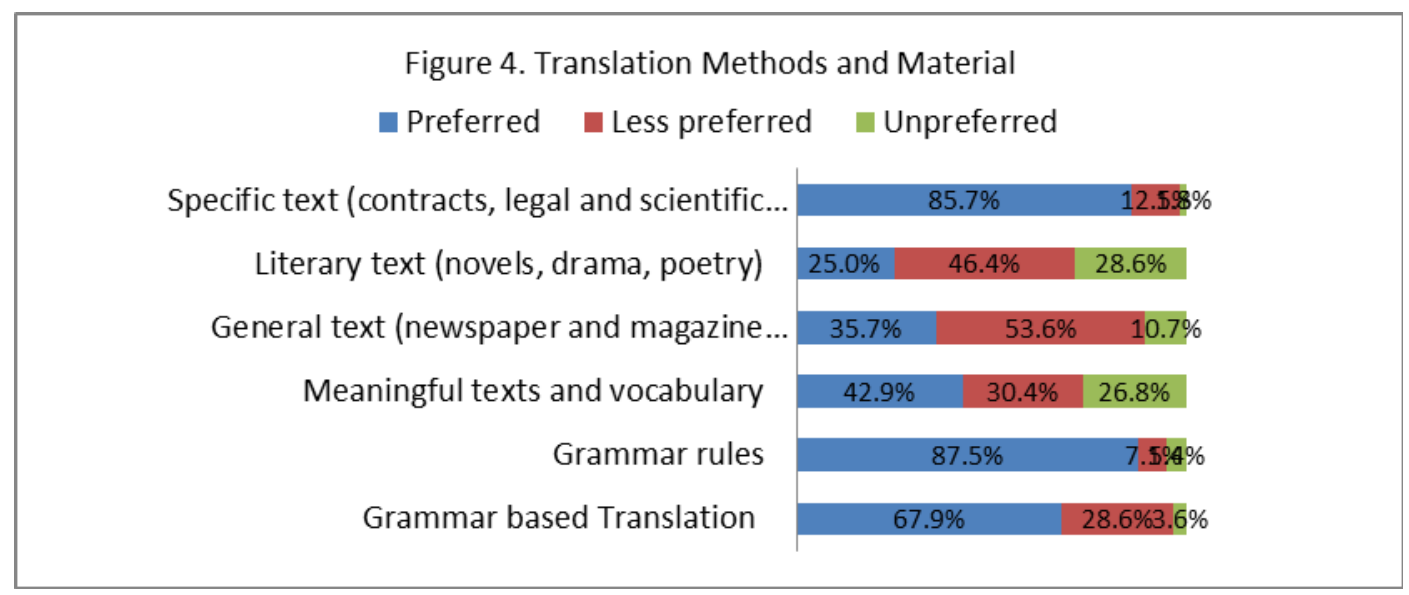

Figure 4. Translation methods and material

\section{A. Translation Methods}

Grammar is a description of the language structure and the way in which units such as words and phrases are combined to produce sentences in the language. Most of students believed that grammar is important. Grammar enables them to better writing. But some students opinion reflect that grammar should not be taught in class, it was wasting time, since the students have learned in for years. Others believe that learning only the grammatical rules was not enough, and that learners had to practice the language and apply these rules in their speaking and communication with others in order to attain fluency.

In line with the previous results, students reported that $41 \%$ of students like grammar translation learning. They also aware the benefit of grammar rules during writing and speaking. Students also prefered meaning full and vocabulary and listening comprehension in class.

The students reported the importance of self-selecting their words to study because this ensured they were learning new words. Students were able to personalize word learning by choosing words they felt were important and then 
create original representations of the words. We can conclude from this finding that students are aware of the benefits of developing writing and grammar. Thus this is being a notice in further study.

The real usefulness of translation in English classes lies in exploiting it in order to compare grammar, vocabulary, word order and other language points in English and the student's mother tongue.

\section{B. Materials}

48 of 56 students $(75.0 \%)$ preferred the specifict text as translating materials compared to general text (33.9\%). While literary text is less preferred $(17.9 \%)$. Studenst aware that the specific text offer the appropriate vocabularies that fit to their educational background. Studies reveal that learn to translate specific text focus on developing English communication skills in a specific discipline. By consideration to respondents education background, specific text is also suitable in for non-transtranslation class teaching, such as legal text, finance, marketing, management, and engineering (Siregar, 2017: 181). It gives the access specific vocabularies on student educational background. By doing so, students have the appropriate style and tone for their professional discipline and giving opportunities to their career advancement in the future.

\subsection{Preferred Learning Methods and Classroom Interaction}

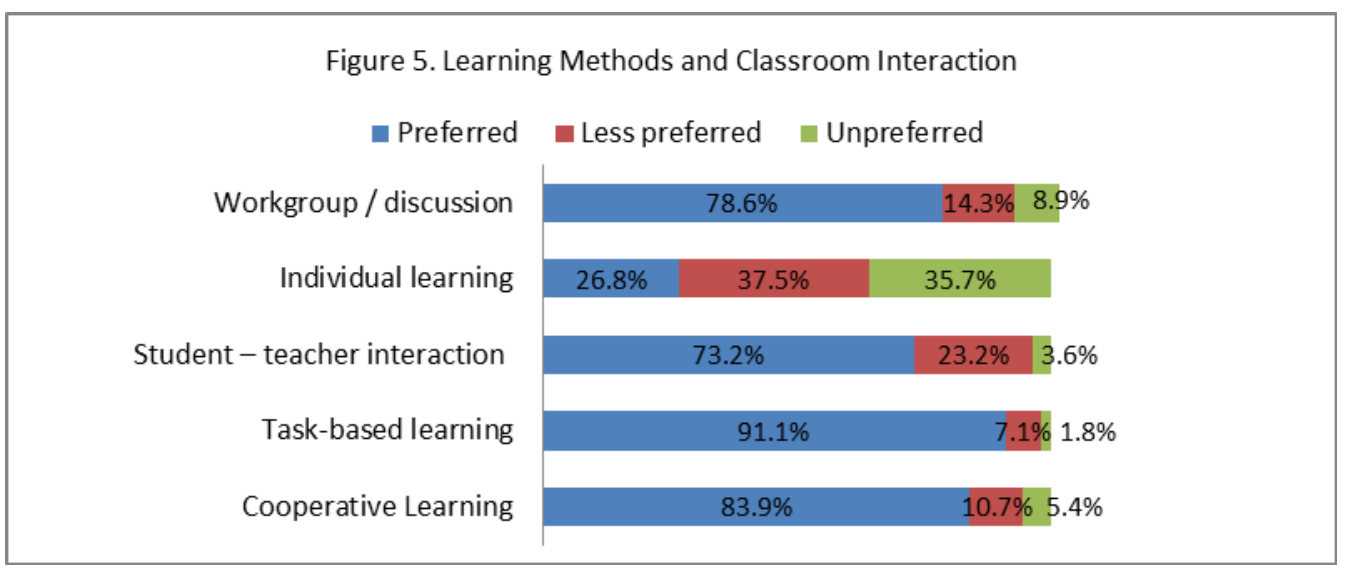

Figure 5. Learning methods and classroom interaction

\section{A. Learning Methods}

Concerning the learning methods, the students' respond to questionnaire shows the comparison of both learning methods. Cooperative learning (91.1\%) slightly preferred than task-based learning $(87.5 \%)$.

Cooperative learning is a teaching method where students of mixed levels of ability are arranged into groups and rewarded according to the group's success, rather than the success of an individual member. Johnson and Johnson (2009) state that the responsibilities of the teacher prior to implementing cooperative learning include formulating educational and social objectives, planning group sizes, determining the criteria for forming groups, defining the roles to be accorded to individual group members, catering to the equipment needed to complete the assignments, and organising the classroom. Task-based learning is a learning approach that makes the performance of meaningful tasks central to the learning process. It based on the use of tasks as the core unit of planning and instruction in language teaching. Task-based learning offers the student an opportunity to do exactly what the teacher command. (Richards \& Rodgers, 2001; Harmer, 2007).

Students respons to workgroup/discussion is high, 41 (73.2\%) respondents prefer workgroup. Students opinion revealed that the workgroup help them to solve the task much easier than individually. However, it may increases the amount of talking time. Harmer (2001) argued in workgroup learning, students willingly contribute in the interaction and offer different ideas and varied opinions.

\section{B. Classroom Interaction}

Students interaction in group will benefit for the learners when they are well structured and managed by teacher. Johnson (1995) suggests that student's interaction in group is an important factor of cognitive development, educational achievement of students and emerging social competencies and develop the learners' capacities through collaborative.

The quality of the discussion is also important: tasks that have the potential for more than one answer can 
generate deeper thinking processes and may also shift the direction of the lesson. In-class assignments where students think individually about a question, talk to their peers about an idea, and then report their findings back to the class. Therefore, teachers and students should consider it as an essential part in learning and teaching language skills, especially in speaking class. They also added that classroom interaction helps the teachers to manage who should talk, to whom, on what topic, in what language.

According to the classroom interaction which is a productive teaching technique manages the classroom language learning. Interaction is face-to-face communication with Particular prosody, facial expression, silence, and rhythmical patterns of behavior between the participants. Interaction also provides opportunities for production and receiving feedback. Classes that have low interaction among students are more teacher-focused, often well-organized, and tend to present material clearly.

\subsection{Student Willingness and Course Length Expectation}

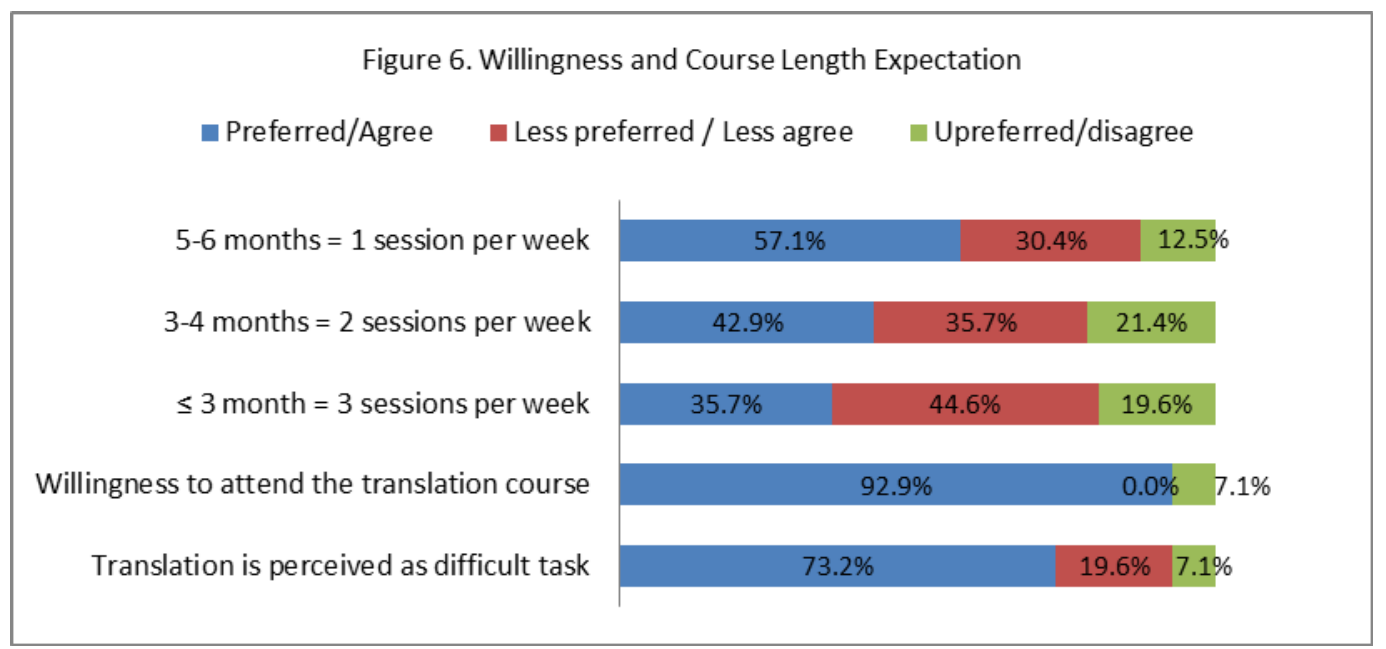

Figure 6. Willingness and course length expectation

The questionnaire result concerning the student prefences on willingness and time invested to translation course are: $76.8 \%$ of students aware the importance of translation and $87.5 \%$ state the willingness to attend the course. Related to course length, 32 of $56(76.8 \%)$ of students preferred the longer course with 1 session per week, while the shorter length course ( $\leq 3$ months) with more session is preferred by 20 students (35.7\%). Apparently students preferred the longer course with less session by regarding their routine activity schedule.

Two other closed ended question were asked asked for students. The students respons to the first question shows that 41 students $(73.2 \%)$ perceived translation as a difficult task. Despite translation is perceived as difficult question, the respond to the second question showed that 52 students $(92.9 \%)$ agree to attend the translation course. The students commentaries on the third questions above reveals that most of them aware the usefulness of translation and they are motivated to learn.

\section{Conclusion}

Through translation teaching, students deepen their understanding of two languages and two cultures, and enhance their knowledge of structure. From the students' point of view, the EFL skill that most important in translation learning is speaking and writing. It is along with the students perception on second question, where the grammar rules is very important in doing translation. The student response depict that grammar is the key to good writing, because of poorly punctuated and contains grammatical errors is difficult to read and sometimes impossible to understand. Languages are dynamic, evolves and expands in vocabulary. Thus the reading activity and skill will enrich their vocabularies that needed in translation.

Students' response on translation assigment revealed that translation is involved in non-translation class. The students on fifth semester responded that they were asked to learn more theories in English textbook. In dealing with the English textbook, most of students used machine translation such as Google Translator as aided tools. Thus, we simply concluded that translation is needed in non-translation class.

Students response on learning methods and interaction suggest that the students most likely working in 
group/discussion and interact with their teacher and hesitate to work individually. It is accordance with their response to the translation that perceived as the difficult task. The students high respond on willingness to attend the course reveals their interest and motivation to attend the translation class with various preferred length of time invested. Thus, by understanding this learners'perceptions, the reasearcher has the firm consideration in developing a suitable translation course design for undergraduate students.

\section{Acknowledgments}

This research was supported by Indonesian Government through The Ministries Of Research, Technology, And Higher Education Republic Of Indonesia (Ristekdikti). I also very grateful to Syahron Lubis, Sondang Manik, Milisi Sembiring, and Gavin Yu who provided insight and expertise that assisted the writing of this paper.

\section{References}

Atkinson, D. (1993). Teaching Monolingual Classes. London: Longman

Aguado, T. M., \& Solís-Becerra, J. (2013). An Overview of Translation In Language Teaching Methods: Implications for EFL in Secondary Education In The Region Of Murcia. RLyLA, 08, 38-48.

Ardi, H. (2012). Is Theory of Translation Needed to Build Students' Translation Competence? Proceeding of Internatlonal Seminar on Languages and Arts: ISL. p. 323.

Calis, E., \& Dikilitas, K. (2012). The Use of Translation In EFL Classes as L2 Learning Practice. Procedia Social and Behavioral Sciences, 46. https://doi.org/10.1016/j.sbspro.2012.06.389

Carreres, A. (2006, December). Strange bedfellows: Translation and language teaching. The teaching of translation into L2 in modern languages degrees: Uses and limitations. In Sixth Symposium on Translation, Terminology and Interpretation in Cuba and Canada. Canadian Translators, Terminologists and Interpreters Council. Retrieved from http://www.cttic.org/publications_06Symposium.asp.

Conacher, J. E. (1996). Native Speaker to Native Speaker: Crossing the Translation Gap. In P. Sewell, \& I. Higgins (Eds.), Teaching Translation in Universities. Present and Future Perspectives (pp. 161-182). London: Association for French Language Studies \& Centre for Information on Language Teaching and Research.

Ellis, R. (1992). Second Language Acquisition \& Language Pedagogy. Clevedon: Multilingual Matters Ltd. https://doi.org/10.1017/S0272263100010512

Eadie, J. (1999). A Translation Technique. ELT Forum, 37(1), 2-9.

Flórez, E. G. (2012). EFL Students' Perceptions about a Web-Based English Reading Comprehension Course. PROFILE, 14(2).

Harmer, J. (1991). The Practice of English Language Teaching. London: Longman.

Harmer, J. (2001). The practice of English language teaching (3rd edition). Longman.

Harmer, J. (2007). The practice of English language teaching (4th ed). Harlow: Pearson Education. https://doi.org/10.1093/elt/ccn029

Hung, E. (2002). Teaching Translation and Interpreting 4: Building bridges. John Benjamin Translation Library. https://doi.org/10.1075/btl.42

Ivone, M. F. (2005). Teaching English as A Foreign Language in Indonesia: The Urge to Improve Classroom Vocabulary Instruction. TEFLIN Journal, 1(2), 198.

Kelly, N., \& Bruen, J. (2015). Translation as a pedagogical tool in the foreign language classroom: A qualitative study of attitudes and behaviours. Language Teaching Research. https://doi.org/10.1177/1362168814541720

Larson, M. (1986). Techniques and Principles in Language Teaching. Oxford: Oxford University Press.

Littlewood, W. (1981). Communicative language teaching: An introduction. Cambridge: Cambridge University Press.

Johnson, K. E. (1995). Understanding Communication in Second Language Classroom. Cambridge: Cambridge University Press.

Johnson, D. W., \& Johnson, R. T. (2009). Introduction to Cooperative Learning. An Overview Of Cooperative Learning. Retrieved from http://www.co-operation.org/home/introduction-tocooperative-learning 
Mogahed M. (2011). To Use or not to Use Translation in Language Teaching. Translation Journal, 15(4).

Popovic, R. (2001). The Place of Translation in Language Teaching. Paper in English Teaching Forum, 37(2).

Reeve J. (2009). Why Teachers Adopt a Controlling Motivating Style Toward Students and How They Can Become More Autonomy Supportive. Educational Psychologist. https://doi.org/10.1080/00461520903028990

Richards J. C., \& Rodgers, T. S. (2001). Approaches and Methods in Language Teaching. Cambridge University Press, Cambridge, England. https://doi.org/10.1017/CBO9780511667305

Ross, N. J. (2000). Interference and Intervention: Using Translation in the EFL Classroom. Modern English Teacher, 9(3).

Siregar, R. (2017). Teaching Specific Purpose Translation: Utilization of Bilingual Contract Document as Parallel Corpus. English Language Teaching, 10(7), 175-182. https://doi.org/10.5539/elt.v10n7p175

Shiyab \& Abdul, L. (2001). Translation and Foreign Language Teaching. Journal of King Saud University Language \& Translation, 13(1).

Shiyab \& Abdullateeef. (2001). Translation and Foreign Language Teaching.

Sunardi, D. (207). Pengembangan Metode Pengajaran “Translation” Yang Efektif. Lingua Didaktika, 11(2), 320.

Tisgam, K. H. (2009). Is it possible to teAch translation In the classroom? J. Of College Of Education For Women, $20(2)$

Ur, P. (1996). A Course in Language Teaching. Cambridge: Cambridge University Press.

Wang, P. J. (2009) A Study Of Teacher And Student Perceptions Concerning Grammar-Translation Method And Communicative Language Teaching. Department of Applied Foreign Language, Nanya Institute of Technology. p. 149.

Vermes, A. (2010). Translation in Foreign Language Teaching: A Brief Overview of Pros and Cons. Eger Journal of English Studies, 10, 83-93.

\section{Appendix}

Table 1. Student perception on importance of English subject matters in translation

\begin{tabular}{|c|c|c|c|c|}
\hline \multirow{2}{*}{\multicolumn{2}{|c|}{ Characteristic }} & \multicolumn{3}{|c|}{ Rank } \\
\hline & & A & B & $\mathrm{C}$ \\
\hline \multicolumn{5}{|c|}{ 1) Relevance of English subject to translation } \\
\hline 1 & Listening & 33 & 18 & 5 \\
\hline 2 & Speaking & 41 & 14 & 1 \\
\hline 3 & Reading & 20 & 15 & 21 \\
\hline 4 & Writing & 45 & 8 & 3 \\
\hline
\end{tabular}

Table 2. Students experience on translation assignment

\begin{tabular}{|c|c|c|c|c|}
\hline \multirow{2}{*}{\multicolumn{2}{|c|}{$\begin{array}{l}\text { Questionnaire Items } \\
\text { 2) Translation assignment students had before }\end{array}$}} & \multicolumn{3}{|c|}{ Respons } \\
\hline & & \multicolumn{3}{|c|}{ Frequency } \\
\hline 1 & 0 assigment & \multicolumn{3}{|l|}{0} \\
\hline 2 & 1 to 3 assignment(s) & \multicolumn{3}{|l|}{31} \\
\hline \multirow[t]{2}{*}{3} & more than 3 assignments & \multicolumn{3}{|l|}{25} \\
\hline & & \multicolumn{3}{|c|}{ Rank } \\
\hline \multicolumn{2}{|c|}{ 3) Translation aids } & A & B & $\mathrm{C}$ \\
\hline 1 & Manual translation by using dictionary/online dictionary & 9 & 11 & 36 \\
\hline 2 & Using machine translation/software & 41 & 13 & 2 \\
\hline 3 & Using translation service & 32 & 19 & 5 \\
\hline
\end{tabular}


Table 3. Students perception on usability of translation skill

\begin{tabular}{|c|c|c|c|c|}
\hline \multirow{2}{*}{\multicolumn{2}{|c|}{ Questionnaire Items }} & \multicolumn{3}{|c|}{ Respons } \\
\hline & & A & B & $\mathrm{C}$ \\
\hline \multicolumn{5}{|c|}{ 4) Usability of translation } \\
\hline 1 & Help students for further information resources in English & 36 & 12 & 8 \\
\hline 2 & Finding better job or career & 40 & 15 & 1 \\
\hline 3 & A skill students need for higher education & 27 & 23 & 6 \\
\hline
\end{tabular}

Table 4. Translation methods and material

\begin{tabular}{|c|c|c|c|c|}
\hline \multirow{2}{*}{\multicolumn{2}{|c|}{ Questionnaire Items }} & \multicolumn{3}{|c|}{ Rank } \\
\hline & & A & B & $\mathrm{C}$ \\
\hline \multicolumn{5}{|c|}{ 5) Translation methods } \\
\hline 1 & Grammar based Translation & 38 & 16 & 2 \\
\hline 2 & Grammar rules & 52 & 4 & 0 \\
\hline 3 & Meaningful texts and vocabulary & 24 & 17 & 15 \\
\hline \multicolumn{5}{|c|}{ 6) Written material in translation: } \\
\hline 1 & General text (newspaper and magazine articles) & 20 & 30 & 6 \\
\hline 2 & Literary text (novels, drama, poetry) & 14 & 26 & 16 \\
\hline 3 & Specific text (contracts, legal and scientific texts.) & 48 & 7 & 1 \\
\hline
\end{tabular}

Table 5. Learning methods and material

\begin{tabular}{|c|c|c|c|c|}
\hline \multirow{2}{*}{\multicolumn{2}{|c|}{ Questionnaire Items }} & \multicolumn{3}{|c|}{ Rank } \\
\hline & & A & B & $\mathrm{C}$ \\
\hline \multicolumn{5}{|c|}{ 7) Preferred learning methods: } \\
\hline 1 & Cooperative Learning & 47 & 6 & 3 \\
\hline 2 & Task-based learning & 51 & 4 & 1 \\
\hline \multicolumn{5}{|c|}{ 8) Clasroom interaction } \\
\hline 1 & Student - teacher interaction & 41 & 13 & 2 \\
\hline 2 & Individual learning & 15 & 21 & 20 \\
\hline 3 & Workgroup / discussion & 41 & 8 & 7 \\
\hline
\end{tabular}

Table 6. Student willingness and course length expectation

\begin{tabular}{|c|c|c|c|c|}
\hline \multirow{2}{*}{\multicolumn{2}{|c|}{ Questionnaire Items }} & \multicolumn{3}{|c|}{ Rank } \\
\hline & & $\mathrm{B}$ & $\mathrm{C}$ & $\mathrm{C}$ \\
\hline \multicolumn{5}{|c|}{ 9) Willingness to attend the translation course } \\
\hline 1 & Perceive translation is a difficult task & 41 & 11 & 4 \\
\hline 2 & Willingness to attend the translation course & 52 & 0 & 4 \\
\hline \multicolumn{5}{|c|}{ 10) Expectation to time invested } \\
\hline 1 & $\leq 3$ month $=3$ sessions per week & 20 & 25 & 11 \\
\hline 2 & $3-4$ months $=2$ sessions per week & 24 & 20 & 12 \\
\hline 3 & $5-6$ months $=1$ session per week & 32 & 17 & 7 \\
\hline
\end{tabular}

Description: A = Preferred/Agree; $\mathrm{B}$ = Less preferred/Less agree; $\mathrm{C}$ = Unpreferred/Disagree 


\section{Copyrights}

Copyright for this article is retained by the author(s), with first publication rights granted to the journal.

This is an open-access article distributed under the terms and conditions of the Creative Commons Attribution license (http://creativecommons.org/licenses/by/4.0/). 